\title{
SOLUBLE CARBOHYDRATES \\ IN CEREAL (WHEAT, RYE, TRITICALE) SEED AFTER STORAGE UNDER ACCELERATED AGEING CONDITIONS
}

\author{
AgNiesZKa I. PiotrowiCZ-CIEŚLAK ${ }^{1}$, MACIEJ NIEDZIELSKI ${ }^{2}$, \\ DARIUSZ J. MiCHALCZYK ${ }^{1}$, WIESŁAW LUCZAK $^{2}$, BARBARA AdOMAS ${ }^{3}$ \\ ${ }^{1}$ Department of Plant Physiology and Biotechnology, \\ University of Warmia and Mazury \\ Oczapowskiego 1A, 10-718 Olsztyn, Poland \\ e-mail: acieslak@uwm.edu.pl \\ ${ }^{2}$ Center for Biological Diversity Conservation of the Polish Academy of Sciences \\ Prawdziwka 2, 02-973 Warszawa, Poland \\ ${ }^{3}$ Department of Air Protection and Environmental Toxicology, \\ University of Warmia and Mazury \\ Prawocheńskiego 17, 10-720 Olsztyn, Poland
}

(Received: August 21, 2009. Accepted: January 27, 2010)

\begin{abstract}
Germinability and the content of soluble carbohydrates were analysed in cereal seed (winter rye, cv. Warko; spring wheat, cv. Santa; hexaploid winter triticale, cv. Fidelio and cv. Woltario). Seed moisture content (mc) was equilibrated over silica gel to $0.08 \mathrm{~g} \mathrm{H}_{2} \mathrm{O} / \mathrm{g}$ dry mass and stored in a desiccator at $20^{\circ} \mathrm{C}$ for up to 205 weeks or were equilibrated to mc $0.06,0.08$ or $0.10 \mathrm{~g} \mathrm{H}_{2} \mathrm{O} / \mathrm{g} \mathrm{dm}$ and subjected to artificial aging at $35^{\circ} \mathrm{C}$ in air-tight laminated aluminium foil packages for 205 weeks. It was shown that the rate of seed aging depended on the species and seed moisture content. The fastest decrease of germinability upon storage was observed in seed with the highest moisture level. Complete germinability loss for winter rye, winter triticale cv. Fidelio, winter triticale cv. Woltario and spring wheat seed with mc $0.10 \mathrm{~g} \mathrm{H}_{2} \mathrm{O} / \mathrm{g} \mathrm{dm}$ occurred after 81, 81, 101 and 133 weeks, respectively. Fructose, glucose, galactose, myo-inositol, sucrose, galactinol, raffinose, stachyose and verbascose were the main soluble carbohydrates found in the seed. The obtained data on the contents of specific sugars and the composition of soluble sugars fraction in seed of rye, wheat and triticale did not corroborate any profound effect of reducing sugars, sucrose and oligosaccharides on seed longevity.
\end{abstract}

KEY WORDS: storage, cereal seed, moisture content, soluble carbohydrates.

\section{INTRODUCTION}

Long-term storage of seed samples is one of the basic and commonly used method for ex-situ conservation of plant genetic resources. The effect of the main factors on seed longevity has been thoroughly studied in the last decades. It has been shown for 'orthodox' seed (Roberts 1973) that lowering their moisture and storage temperature leads to significant increase in storage time (Harrington 1972; Roberts 1972). Based on these results recommendations for optimum seed storage in gene banks have been formulated (FAO/IBGRI 1994). Seed viability loss during the storage proceeds at different rate depending not only on the storage conditions but on the plant species as well (Walters et al. 2005). A sound understanding of the mechanisms underlying seed aging is crucial for long-term storage and it is an interesting cognitive challenge as well.
Aging is a consequence of diverse inter connected biochemical processes (Kristal and Yu 1992; Ying 1997; Baynes 2002). Maillard type reactions in which reducing sugars and products of lipids peroxidation can react with proteins and nucleic acids leading to inactivation of the latter ones (Narayana Murthy al. 2002; Narayana Murthy et al. 2003). Sucrose, cyclitols and their galactosyl derivatives are involved in creation and stabilisation of cell vitrified cytoplasm structure what is vital for cells resistance to dehydratation and slows down the rate of aging (Caffrey et al. 1988; Horbowicz and Obendorf 1994; Bernal-Lugo and Leopold 1992; Steadman et al. 1996).

The aim of the present work was to monitor the soluble carbohydrates content of rye, wheat and triticale seed samples during natural and artificial ageing in an attempt to evaluate interspecies variation and possible effect of soluble carbohydrates on seed longevity. 


\section{MATERIALS AND METHODS}

\section{Seed storage and germinability assessment}

Cereal seed (winter rye, cv. Warko; spring wheat, cv. Santa; winter hexaploid triticale, cv. Fidelio and cv. Woltario), obtained from plant breeding companies, harvested in 2000 were stored in glass desiccator above silica gel at room temperature $\left(20^{\circ} \mathrm{C}\right)$. After two months storage half of the each seed sample was conditioned for two weeks above saturated solution of inorganic salts $\mathrm{ZnCl}_{2}, \mathrm{MgCl}_{2}$, $\mathrm{Ca}\left(\mathrm{NO}_{3}\right)_{2}$ (Winston and Bates 1960) in order to obtain seed of different moisture contents: $0.06,0.08$ and 0.10 $\mathrm{g} \mathrm{H}_{2} \mathrm{O} / \mathrm{g} \mathrm{dm}$, respectively. The samples were then hermetically sealed in laminated aluminium foil and subjected to accelerated aging at constant temperature $\left(35^{\circ} \mathrm{C}\right)$ for 205 weeks. The germinability was checked periodically (every two weeks). Germination tests were performed $(2 \times 20$ seeds) between a dump paper towel for a seven days in a germinating cabinet at day/night temperature $25 / 15^{\circ} \mathrm{C}$ with $16 / 8$ $\mathrm{h}$ photoperiod. Seeds were considered as germinated when the radicle protruded the seed coat at least $1 \mathrm{~mm}$.

\section{Soluble carbohydrates content determination}

After 205 weeks of artificial ageing soluble carbohydrates were extracted from the whole seed and excised embryos as described by Piotrowicz-Cieślak et al. (2003). Briefly, tissues (30-60 mg fresh mass) were homogenised in ethanol : water, $1: 1(\mathrm{v} / \mathrm{v})$ containing $300 \mu \mathrm{g}$ phenyl- $\alpha-\mathrm{D}-$ -glucose as internal standard. The homogenate was combined in a $1.5-\mathrm{ml}$ microfuge tube, heated at $75^{\circ} \mathrm{C}$ for $30 \mathrm{~min}$ to inactivate endogenous enzymes and centrifuged at 15 $000 \mathrm{~g}$ for $20 \mathrm{~min}$. The supernatant was passed through a $0.22 \mu \mathrm{m}$ filter (Spin-X Centrifuge Tube Filter Nylon; Corning NY USA). Aliquots of $0.3 \mathrm{ml}$ filtrate were transferred to silylation vials and evaporated to dryness under a stream of nitrogen. Residues were kept overnight over phosphorus pentoxide in a desiccator. Dry residues were derived with $300 \mu \mathrm{l}$ of silylation mixture (trimethylsilylimidazole : pyridine, 1:1, v/v) in silylation vials (Supelco) at $70^{\circ} \mathrm{C}$ for $30 \mathrm{~min}$ and then cooled at room temperature. One $\mu l$ carbohydrate extract was injected into a split-mode injector of a Shimadzu GC-14A gas chromatograph equipped with flame ionisation detector and Shimadzu C-R6A integrator. Soluble carbohydrates were analysed on a DB-1 capillary column (15 m length, $0.25 \mathrm{~mm}$ ID, 0.25 $\mu \mathrm{m}$ film thickness, J\&W Scientific). Soluble carbohydrates were identified with internal standards as available present and the contents were calculated from the ratios of peak area for each analysed carbohydrate to the peak area of respective internal standard. Quantities of soluble carbohy- drates were expressed as mean \pm SD for 3-5 replications of each treatment.

\section{Statistical analyses}

Differences between soluble carbohydrate contents were analyzed for statistical significance using analysis of variance (ANOVA). Means were separated using Duncan's multiple range tests. All statistical analyses were conducted using Statistica 8.0.

\section{RESULTS AND DISCUSSION}

\section{Seed viability}

Seed stored in a desiccator above silica gel, at moisture content $0.07\left(\mathrm{~g} \mathrm{H}_{2} \mathrm{O} / \mathrm{g} \mathrm{dm}\right)$ did not show any viability loss. The observed slight increase in germination ability (data not showed), was probably a result of partially released post-harvest dormancy of seed samples.

The observed changes of seed viability in artificially aged rye, wheat and triticale seed corresponded to the criteria known for seed of 'orthodox' type (Roberts 1973). Higher moisture content of seed subjected to accelerated aging caused significant increase of seed viability decline rate (Ellis 1998). After the 205 week storage at $35^{\circ} \mathrm{C}$ seed of winter rye and spring wheat with moisture content 0.06 $\mathrm{g} \mathrm{H}_{2} \mathrm{O} / \mathrm{g} \mathrm{dm}$, maintained 10 and $15 \%$, germinability respectively (Table 1). Triticale cultivars showed clear differences in longevity. Seed of cv. Woltario maintained their viability, while seed of cv. Fidelio were completely aged at 137 weeks. Among seeds with mc $0.08 \mathrm{~g} \mathrm{H}_{2} \mathrm{O} / \mathrm{g} \mathrm{dm}$, wheat sample alone remained vigorous but germinated in only $3 \%$; the other seed did not germinate. The increase of seed moisture content to $0.10 \mathrm{~g} \mathrm{H}_{2} \mathrm{O} / \mathrm{g} \mathrm{dm}$ resulted in germinability loss of all seed samples after 205 weeks. A complete germinability loss occurred in winter rye and winter triticale after 81 and 101 weeks (Fig. 1) while seeds of spring wheat remained viable much longer. An effect of the species on seed germinability was apparent. Among the three species, winter rye aged at fastest rate, while wheat - the slowest. Winter hexaploid triticale cultivars aged at a medium rate.

\section{Soluble carbohydrates content and composition}

Total soluble carbohydrates content in seeds seems species specific. It was not significantly different in high viability (control) seed of rye and triticale cultivars, while in wheat it was the lowest (Table 2).

The process of artificial seed ageing differently affected soluble carbohydrate levels, depending on plant species

TABLE 1 . Seed germination after 205 weeks of storage at $20^{\circ} \mathrm{C}$ (control) or $35^{\circ} \mathrm{C}$ (artificially aged seed).

Germination, \%

\begin{tabular}{|c|c|c|c|c|}
\hline \multirow[b]{2}{*}{ Cereal } & & \multirow{2}{*}{\multicolumn{3}{|c|}{$\begin{array}{l}\text { Artificially aged seeds } \\
\text { with } \mathrm{mc}\left(\mathrm{g} \mathrm{H}_{2} \mathrm{O} / \mathrm{g}\right)\end{array}$}} \\
\hline & $\begin{array}{c}\text { Control seeds } \\
\text { with } \mathrm{mc}\left(\mathrm{g} \mathrm{H}_{2} \mathrm{O} / \mathrm{g}\right) \\
0.07\end{array}$ & & & \\
\hline Winter rye, cv. Warko & 90 & 10 & $0(157)^{*}$ & $0(81)$ \\
\hline Hexaploid triticale, cv. Fidelio & 94 & $0(137)$ & $0(125)$ & $0(81)$ \\
\hline Hexaploid triticale, cv. Woltario & 96 & 3 & $0(173)$ & $0(101)$ \\
\hline Spring wheat, cv. Santa & 99 & 15 & 3 & $0(133)$ \\
\hline
\end{tabular}

* in brackets - time (weeks) to complete loss of viability 


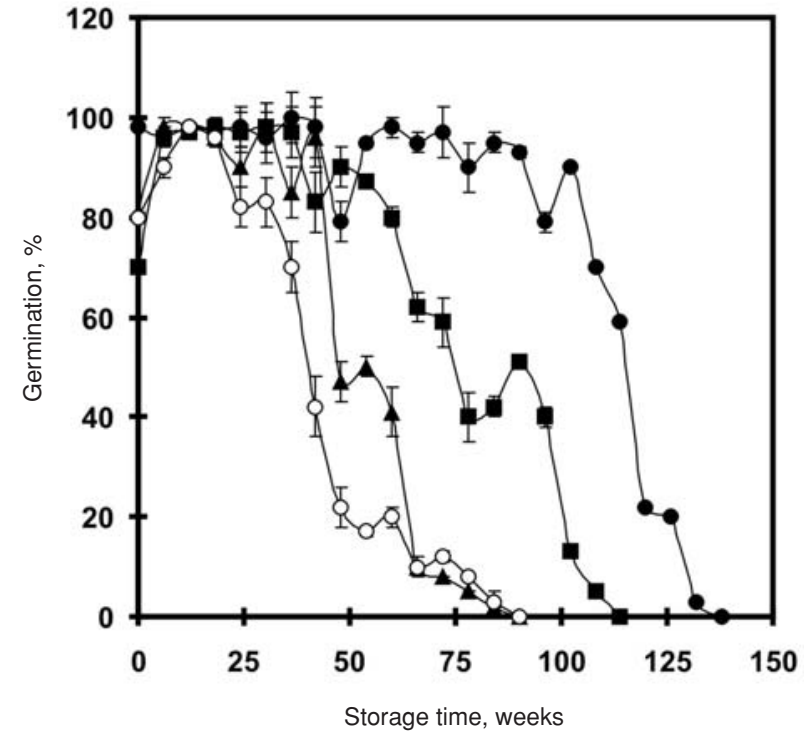

Fig. 1. Changes in seed germination during storage of winter rye (o); triticale cv. Fidelio ( $\mathbf{\Delta})$; triticale cv. Woltario $(\boldsymbol{\square})$ and spring wheat $(\bullet)$ seeds.

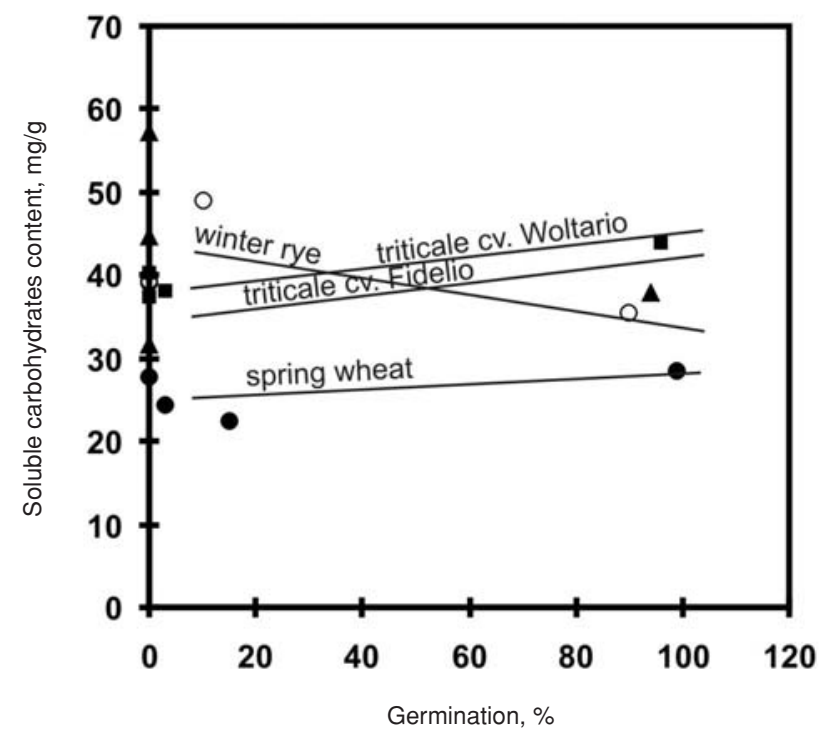

Fig. 2. The effect of seed storage period on total soluble carbohydrates content of the whole seed of winter rye $-\mathrm{o}$; triticale cv. Fidelio $-\mathbf{\Delta}$; triticale cv. Woltario - $\mathbf{\square}$ and spring wheat - seeds. The lines show linear trend for each species/variety.

and - as seen in triticale - variety. In winter rye all seed ageing treatments elevated the amount of carbohydrates, although the differences were small, statistically not significant. In triticale cv. Fidelio all aged seed lots, except se- eds with $0.10 \mathrm{mc}$, increased the content of soluble carbohydrates (statistically significant in seeds with $0.06 \mathrm{mc}$ ). Triticale cv. Woltario, as well as wheat seeds did not increase total carbohydrate levels as a result of accelerated ageing, on the contrary the amount of carbohydrates in theses seeds slightly decreased (Table 2). For all seeds except rye, there was a weak positive relationship between per cent germination and seed carbohydrate level (Fig. 2).

The content of soluble carbohydrates and their composition was also determined in manually isolated embryos. Samples with germinability higher than $0 \%$ were used for the analysis. The total carbohydrates content in embryos was, when calculated per mass unit, several times higher than in the whole seeds (Table 3), which reflects differences in size and chemical composition between whole seeds and cereal embryos. The total carbohydrate content in embryos was clearly species specific. Like in the whole seeds, the total content of soluble sugars in wheat embryos was significantly lower in comparison with rye and triticale. Contrary to the whole seeds, there was a negative correlation between total carbohydrate content of the embryos and seed viability (Fig. 3).

The analysis of carbohydrates composition of whole seeds suggests that the levels of monosaccharides and oligosaccharides were strongly related - in rye and triticale cv. Fidelio the levels of oligosaccharides decreased and a corresponding increase in monosaccharide content was observed. In these seeds disaccharide levels were not clearly affected by seed ageing. In triticale cv. Woltario a sharp decrease in oligosaccharide level accompanied by increased monosccharide level could only be observed in seeds with the highest water content (mc 0.1). Interestingly in theses seeds, unlike triticale cv. Fidelio seeds, ageing resulted in significantly increased levels of disaccharides (Table 4). In wheat seeds only one ageing regimen (mc 0.06) significantly affected monosaccharides (increased) and oligosaccharides (decreased).

In embryos isolated from partially deteriorated seeds the per cent content of carbohydrate fractions did not change as clearly as in the whole seeds, and the amount of disaccharides was higher. Only in wheat embryos accelerated ageing resulted in a very pronounced a decrease of oligosaccharides (Table 5).

For prolonged seed storability the presence and mutual proportions of several basic carbohydrates may be even more important, than total carbohydrate content (Chen and Burris 1990; Bernal-Lugo and Leopold 1992). Monosaccharides are significant as symptoms of ongoing decomposition of polysaccharides, oligo- and disaccharides. Monosaccharides may also act as causative factors in advancing

TABLE 2. Total content of soluble carbohydrates in the whole seeds after 205 weeks of storage at $20^{\circ} \mathrm{C}$ (control) or $35^{\circ} \mathrm{C}(\operatorname{artificially}$ aged seed).

\begin{tabular}{|c|c|c|c|c|}
\hline \multirow[b]{2}{*}{ Cereal } & \multicolumn{4}{|c|}{ Total carbohydrates $(\mathrm{mg} / \mathrm{g} \mathrm{dw} \pm \mathrm{SD})$} \\
\hline & $\begin{array}{c}\text { Control seeds } \\
\text { with } \mathrm{mc}\left(\mathrm{g} \mathrm{H}_{2} \mathrm{O} / \mathrm{g}\right) \\
0.07\end{array}$ & 0.06 & $\begin{array}{c}\text { Artificially aged seeds } \\
\text { with } \mathrm{mc}\left(\mathrm{g} \mathrm{H}_{2} \mathrm{O} / \mathrm{g}\right) \\
0.08\end{array}$ & 0.10 \\
\hline Winter rye, cv. Warko & $35.4 \pm 2.0 \mathrm{a}$ & $49.1 \pm 3.9 \mathrm{a}$ & $39.3 \pm 4.2 \mathrm{a}$ & $39.2 \pm 3.2 \mathrm{a}$ \\
\hline Hexaploid triticale, cv. Fidelio & $37.9 \pm 3.9 \mathrm{a}$ & $57.2 \pm 5.1 \mathrm{~b}$ & $44.6 \pm 4.5 \mathrm{a}$ & $31.6 \pm 1.6 \mathrm{a}$ \\
\hline Hexaploid triticale, cv. Woltario & $44.0 \pm 7.1 \mathrm{a}$ & $38.1 \pm 1.8 b$ & $40.3 \pm 2.1 \mathrm{a}$ & $37.4 \pm 4.0 \mathrm{a}$ \\
\hline Spring wheat, cv. Santa & $28.4 \pm 4.1 b$ & $22.4 \pm 1.6 \mathrm{c}$ & $24.4 \pm 1.8 b$ & $27.7 \pm 2.2 b$ \\
\hline
\end{tabular}

$\mathrm{a}, \mathrm{b}, \mathrm{c} . . .-$ uniform groups based on the Duncan test $\mathrm{p}=0.05$ 
TABLE 3. Total soluble carbohydrates content in the isolated seed embryos after 205 weeks of storage at $20^{\circ} \mathrm{C}$ (control) or $35^{\circ} \mathrm{C}$ (artificially aged seed).

\begin{tabular}{|c|c|c|c|c|}
\hline \multirow[b]{2}{*}{ Cereal } & \multicolumn{4}{|c|}{ Total carbohydrates $(\mathrm{mg} / \mathrm{g} \mathrm{dw} \pm \mathrm{SD})$} \\
\hline & $\begin{array}{c}\text { Control seeds } \\
\text { with } \mathrm{mc}\left(\mathrm{g} \mathrm{H}_{2} \mathrm{O} / \mathrm{g}\right) \\
0.07\end{array}$ & 0.06 & $\begin{array}{c}\text { Artificially seeds aged } \\
\text { with } \mathrm{mc}\left(\mathrm{g} \mathrm{H}_{2} \mathrm{O} / \mathrm{g}\right) \\
0.08\end{array}$ & 0.10 \\
\hline Winter rye, cv. Warko & $301.0 \pm 10.8 \mathrm{a}$ & $371.4 \pm 24.4 \mathrm{a}$ & $331.2 \pm 23.2 \mathrm{a}$ & $338.6 \pm 21.4 \mathrm{a}$ \\
\hline Hexaploid triticale, cv. Fidelio & $407.4 \pm 22.3 b$ & $458.3 \pm 14.8 b$ & $412.2 \pm 18.5 b$ & $443.6 \pm 16.2 b$ \\
\hline Hexaploid triticale, cv. Woltario & $313.0 \pm 16.6 \mathrm{~b}$ & $412.1 \pm 28.7 \mathrm{a}$ & $331.2 \pm 12.3 \mathrm{a}$ & $334.5 \pm 15.1 \mathrm{a}$ \\
\hline Spring wheat, cv. Santa & $191.4 \pm 14.6 \mathrm{c}$ & $233.0 \pm 22.7 \mathrm{c}$ & $247.5 \pm 18.9 \mathrm{c}$ & $247.5 \pm 18.9 c$ \\
\hline
\end{tabular}

$\mathrm{a}, \mathrm{b}, \mathrm{c} \ldots-$ uniform groups based on the Duncan test $\mathrm{p}=0.05$

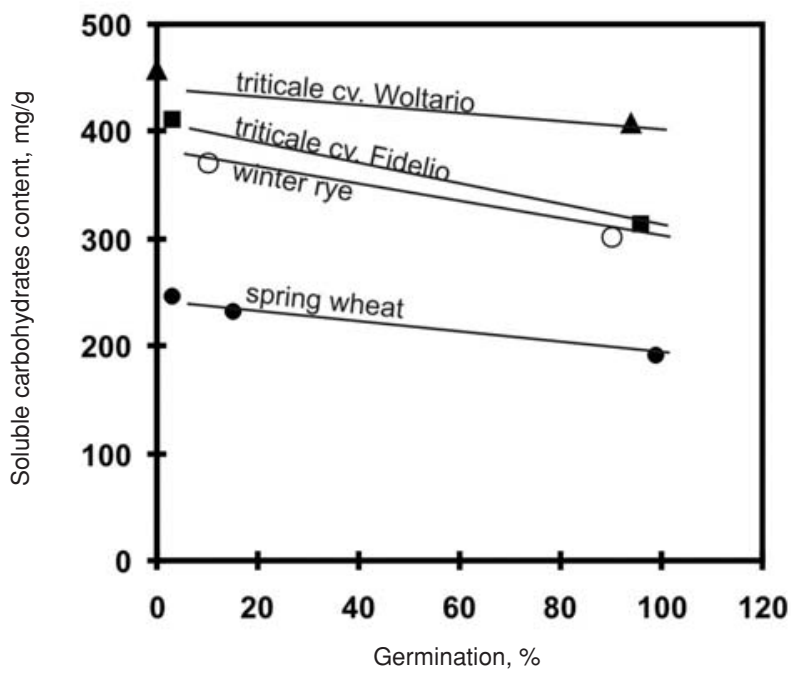

Fig. 3. The effect of seed storage period on total soluble carbohydrates content of the isolated embryos of rye $-\mathrm{o}$; triticale cv. Fidelio $-\mathbf{\Delta}$; triticale cv. Woltario - and wheat - seeds. The lines show linear trend for each species/variety.

seed deterioration by binding proteins and nucleic acids in Maillard type reactions. Sucrose and oligosaccharides on the other hand are supposed to promote seed longevity by stabilising cell membranes and imposing the vitrification state on the cytoplasm. The decrease of raffinose content in stored seeds has been correlated with decreased germinability (Horbowicz and Obendorf 1994; Piotrowicz-Cieślak 2005). Sucrose, raffinose and its homologues are supposed to be the key factors stabilising the cell structure during dehydratation, and dry storage.

Nevertheless no simple relationship between seed vigour and seed carbohydrate contents should be expected. Bernal-Lugo and Leopold (1992) observed decrease of monosaccharides content in aged corn. In turn, Narayana Murthy and Sun (2000) observed increase of glucose content in deteriorating mung bean seeds and related it with increase of Maillard reaction products (Monnier 1989). Horbowicz (1997) describes various changes of mono- and oligosaccharides content in vegetable seeds during aging. On the other hand no correlation between seed germinability and oligosaccharides content was observed by Kataki et al. (1997).

The data described in this paper show that accelerated ageing clearly affected carbohydrate levels in cereal seeds, however the patterns of these changes strongly depended on plant species/cultivar and ageing conditions, thus no simple universally valid principle could be formulated.

TABLE 4. Composition soluble carbohydrates fraction in whole seed after 205 weeks of storage at $20^{\circ} \mathrm{C}$ (control) or $35^{\circ} \mathrm{C}$ (artificially aged seed).

\begin{tabular}{|c|c|c|c|c|c|}
\hline \multirow{2}{*}{ Cereal } & \multirow{2}{*}{$\begin{array}{c}\mathrm{mc} \\
\left(\mathrm{g} \mathrm{H}_{2} \mathrm{O} / \mathrm{g} \mathrm{dm}\right)\end{array}$} & \multirow{2}{*}{ Germination, $\%$} & \multicolumn{3}{|c|}{ Soluble carbohydrates, $\%$ of total amount } \\
\hline & & & Monosaccharides & Disaccharides & Oligosaccharides \\
\hline \multirow[t]{4}{*}{ Winter rye, cv. Warko } & 0.07 & 90 & $11.8 \mathrm{a}$ & $46.5 \mathrm{a}$ & $41.7 \mathrm{a}$ \\
\hline & 0.06 & 10 & $8.1 \mathrm{a}$ & $50.2 \mathrm{a}$ & $41.7 \mathrm{a}$ \\
\hline & 0.08 & $\mathbf{0}$ & $9.1 \mathrm{a}$ & $45.6 \mathrm{a}$ & $45.3 \mathrm{a}$ \\
\hline & 0.1 & $\mathbf{0}$ & $15.0 \mathrm{a}$ & $45.2 \mathrm{a}$ & $39.8 \mathrm{a}$ \\
\hline \multirow[t]{4}{*}{ Hexaploid triticale, cv. Fidelio } & 0.07 & 94 & $5.5 b$ & $43.4 \mathrm{a}$ & $51.1 \mathrm{~b}$ \\
\hline & 0.06 & $\mathbf{0}$ & $5.9 \mathrm{~b}$ & $42.6 \mathrm{a}$ & $51.5 b$ \\
\hline & 0.08 & $\mathbf{0}$ & $6.7 \mathrm{~b}$ & $43.0 \mathrm{a}$ & $50.3 b$ \\
\hline & 0.1 & $\mathbf{0}$ & $11.4 \mathrm{a}$ & $44.1 \mathrm{a}$ & $44.5 \mathrm{a}$ \\
\hline \multirow[t]{2}{*}{ Hexaploid triticale, cv. Woltario } & 0.07 & 96 & $8.0 \mathrm{a}$ & $48.7 \mathrm{a}$ & $43.3 \mathrm{a}$ \\
\hline & 0.06 & 3 & $8.6 \mathrm{a}$ & $66.2 b$ & $25.2 \mathrm{c}$ \\
\hline \multirow[t]{4}{*}{ Spring wheat, cv. Santa } & 0.07 & 99 & $4.5 b$ & $47.5 \mathrm{a}$ & $47.9 \mathrm{~b}$ \\
\hline & 0.06 & 15 & $18.4 \mathrm{c}$ & $48.1 \mathrm{a}$ & $28.6 \mathrm{c}$ \\
\hline & 0.08 & 3 & $12.5 \mathrm{a}$ & $50.6 \mathrm{a}$ & $36.9 \mathrm{a}$ \\
\hline & 0.1 & 0 & $10.8 \mathrm{a}$ & $47.1 \mathrm{a}$ & $42.1 \mathrm{a}$ \\
\hline
\end{tabular}

$\mathrm{a}, \mathrm{b}, \mathrm{c} . . .-$ uniform groups based on the Duncan test $\mathrm{p}=0.05$ 
TABLE 5. Composition soluble carbohydrates fraction in isolated seed embryo after 205 weeks of storage at $20^{\circ} \mathrm{C}$ (control) or $35^{\circ} \mathrm{C}$ (artificially aged seed).

\begin{tabular}{|c|c|c|c|c|c|}
\hline \multirow{2}{*}{ Cereal } & \multirow{2}{*}{$\begin{array}{c}\mathrm{mc} \\
\left(\mathrm{g} \mathrm{H}_{2} \mathrm{O} / \mathrm{g} \mathrm{dm}\right)\end{array}$} & \multirow{2}{*}{ Germination, $\%$} & \multicolumn{3}{|c|}{ Soluble carbohydrates, $\%$ of total amount } \\
\hline & & & Monosaccharides & Disaccharides & Oligosaccharides \\
\hline \multirow[t]{2}{*}{ Winter rye, cv. Warko } & 0.07 & 90 & $5.7 \mathrm{a}$ & $83.6 \mathrm{a}$ & $10.7 \mathrm{a}$ \\
\hline & 0.06 & 10 & $6.0 \mathrm{a}$ & $83.4 \mathrm{a}$ & $10.6 \mathrm{a}$ \\
\hline \multirow[t]{2}{*}{ Hexaploid triticale, cv. Fidelio } & 0.07 & 94 & $1.6 \mathrm{c}$ & $85.3 \mathrm{a}$ & $13.1 \mathrm{a}$ \\
\hline & 0.06 & $\mathbf{0}$ & $1.7 \mathrm{c}$ & $83.3 \mathrm{a}$ & $15.0 \mathrm{a}$ \\
\hline \multirow[t]{2}{*}{ Hexaploid triticale, cv. Woltario } & 0.07 & 96 & $5.8 \mathrm{a}$ & $82.4 \mathrm{a}$ & $11.8 \mathrm{a}$ \\
\hline & 0.06 & 3 & $4.0 \mathrm{~b}$ & $83.5 \mathrm{a}$ & $12.5 \mathrm{a}$ \\
\hline \multirow[t]{2}{*}{ Spring wheat, cv. Santa } & 0.07 & 99 & $3.8 \mathrm{~b}$ & $68.2 b$ & $47.9 \mathrm{~b}$ \\
\hline & 0.06 & 15 & $4.6 \mathrm{ab}$ & $64.3 b$ & $28.0 \mathrm{c}$ \\
\hline
\end{tabular}

$\mathrm{a}, \mathrm{b}, \mathrm{c} \ldots-$ - uniform groups based on the Duncan test $\mathrm{p}=0.05$

\section{LITERATURE CITED}

BAYNES J.W. 2002. The Maillard hypothesis on aging: time to focus on DNA. J. N.Y. Acad. Sci., 959: 360-367.

BERNAL-LUGO I., LEOPOLD A.C. 1992. Changes in soluble carbohydrates during seed storage. Plant Physiol. 98: 12071210.

CAFFREY M., FONSECA V., LEOPOLD C.A. 1988. Lipid-sugar interaction. relevance to anhydrous biology. Plant Physiol. 86: 754-758.

CHEN Y., BURRIS J.S. 1990. Role of carbohydrates in desiccation tolerance and membrane behaviour in maturing maize seed. Crop Sci. 30: 971-975.

ELLIS R.H. 1998. Longevity of seed stored hermetically at low moisture contents. Seed Sci. Res., 8, Supplement No. 1, 9-11.

FAO/IBGRI 1994. Genebank standards. Food and Agriculture Organization of the United Nations, International Plant Genetic Resources Institute, Rome, 9-42.

HARRINGTON J.F. 1972. Seed storage and longevity. In: Kozlovski T.T. (ed.), Seed Biol., Acad. Press, N.Y., London, v. 3: 145-246.

HORBOWICZ M. 1997. Changes of carbohydrate contents during natural and accelerated ageing of same vegetable seed. In: Ells R.H., Black M., Murdoch A.J., Hong T.D. (eds), Basic and applied aspects of seed biology. Proceedings of the fifth international workshop on seed. Reading UK, 10-15 Sept. Curr. Plant Sci. Biotechnol. Agric., 30: 803-808.

HORBOWICZ M., OBENDORF R.L. 1994. Seed desiccation tolerance and storability: dependence on flatulence-producing oligosaccharides and cyclitols - review and survey. Seed Sci. Res. 4: 385-407.

KATAKI P.K., HORBOWICZ M., TAYLOR A.G., OBENDORF R.L. 1997. Changes In sucrose, cyclitols and their galactosyl derivatives with seed ageing. In: Ells R.H., Black M., Murdoch A.J., Hong T.D. (eds), Basic and applied aspects of seed biology. Proceedings of the fifth international workshop on seed. Reading UK, 10-15 Sept. Curr. Plant Sci. Biotechnol. Agric., 30: 515-522.
KRISTAL B.S., YU B.P. 1992. An emerging hypothesis: synergistic induction of aging by free radicals and Maillard reactions. J. Gerentol. 47: B107-14.

MONNIER V.M. 1989. Toward Maillard reaction theory of aging. Prog. Clin. Biol. Res. 304: 1-22.

NARAYANA MURTHY U.M., LIANG Y., KUMAR P.P., SUN W.Q. 2002. Non-enzymatic protein modification by the Maillard reaction reduces the activities of scavenging enzymes in Vigna radiate. Physiol. Plant. 115: 213-220.

NARAYANA MURTHY U.M., SUN W.Q. 2000. Protein modification by Amadori and Maillard reactions during seed storage: role of sugar hydrolisis and lipid peroxidation. J. Exp. Bot. 51: 1221-1228.

NARAYANA MURTHY U.M., KUMAR P.P., SUN W.Q. 2003. Mechanism of seed ageing under different storage conditions for Vigna radiata (L.) Wilczek: lipid peroxidation, sugar hydrolysis, Maillard reactions and their relationship to glass state transition. J. Exp. Bot. 54: 1057-1067.

PIOTROWICZ-CIEŚLAK A.I. 2005. Changes in soluble carbohydrates in yellow lupin seed under prolonged storage. Seed Sci. Tech. 33 (1): 141-145.

PIOTROWICZ-CIEŚLAK A.I., LOPEZ P.M.G., GULEWICZ K. 2003. Cyclitols, galactosyl cyclitols and raffinose family oligosaccharides in Mexican wild lupin seeds. Acta Soc. Bot. Pol. 72 (2): 109-114.

ROBERTS E.H. 1972. Storage environment and control of viability. In: Roberts E.H., (ed.), Viability of seed. Syracuse, NY: Syracuse Univ. Press, 14-58.

ROBERTS E.H. 1973. Predicting the storage life of seed. Seed Sci.Tech. 1, 499-514.

STEADMAN K.J., PRITCHARD H.W., DEY P.M. 1996. Tissuespecific soluble sugars in seed as indicators of storage category. Ann. Bot. 77: 667-674.

WALTERS C., WHEELER L.M., GROTENHUIS J.M. 2005. Longevity of seed stored in a genebank: species characteristics. Seed Sci. Res. 15: 1-21.

WINSTON P.W., BATES D.H. 1960. Saturated solutions for the control of humidity in biological research. Ecology 41: 232-237.

YING W. 1997. Deleterious network hypthesis of aging. Med. Hypothesis. 48; 143-148. 